\title{
ANALYSIS OF LAND USE AND LAND COVER DYNAMICS USING REMOTE SENSING AND GIS IN THE UPPER TAMIRAPARANI WATERSHED OF TAMIL NADU, INDIA
}

\author{
SANTHANAKRISHNAN, P. T. ${ }^{*}$ - AMBUJAM, N. K. - NARAYANAN, M. \\ Centre for Water Resources, Anna University, Chennai, Tamil Nadu 600025, India \\ *Corresponding author \\ e-mail: santhanakrishnan.pt@gmail.com
}

(Received 31 $1^{\text {st }}$ Mar 2020; accepted $10^{\text {th }}$ Jun 2021)

\begin{abstract}
Analysing the land use and land cover change along with its cause and consequence on the livelihood of people as well as on the environment is important for sustainable development and management of natural resources. The present study focuses on analysis of land use and land cover dynamics using Landsat images with $30 \mathrm{~m}$ spatial resolution for upper Tamiraparani watershed located in Tamil Nadu state in India. ArcGIS 10.3 and ERDAS Imagine 14 have been used for the image processing to produce five land use and land cover classes in the watershed. The results after classification indicates that over the past 17 years, expansion of urban built-up and agricultural land have increased at a rate of 195.2 ha/year and 37.1 ha/year respectively and contrary to this the share of forest land, barren land and water bodies shrunk with the rate of $118.2 \mathrm{ha} /$ year, $96.6 \mathrm{ha} /$ year and $17.6 \mathrm{ha} /$ year respectively. It is understood that the urban built-up has intensively expanded at the expense of other land use and land cover without significant conservation measure. In particular, integrated approach with community participation is required in the watershed development for management of natural resources and sustainable development.
\end{abstract}

Keywords: image processing, ecosystem conservation, environment, urban sprawl, ArcGIS and ERDAS

\section{Introduction}

Land use and land cover dynamics have become a major concern in the twenty first century, with remarkable implications for human survival. Land cover change refers to the change in the physical and biological characteristics of land on account of the modification of natural environments into built environments such as settlements or farm land for agricultural activities (Prakasam, 2010; Dezso et al., 2005). Recently, the research on land use and land cover change has drawn the attention of the researchers since these dynamics affect the hydrological cycle, natural biodiversity, land productivity and sustainability of the natural ecosystem (Nurelegn and Amare, 2014; Minale and Rao, 2012). This land use dynamics in recent years plays a wide role as driving force in alternating the global environment (Bae and Ryu, 2014).

Land use and land cover change detection is essential for better understanding of landscape dynamic during a known period of time having sustainable management (Praveen Kumar and Sreenivasula Reddy, 2013). According to Abbas et al. (2010) alteration in land use and land cover significantly aggravates the phenomenon like soil erosion, land degradation, increased surface runoff, siltation, sedimentation, drought, migration, desertification with loss of biodiversity, decrease in productivity and famine. Though we have many controversies on the factors affecting land cover dynamics, few research studies states that demographic factor intensively hasten the land use dynamics (Abate, 2011). Increase in rate of population, insecure land use right and lack of credit facilities are some of the socio-economic factors which facilitates for the change of land 
use and land cover. For the poor those are living under subsistence farming has no other option other than exploiting available natural resource. In major parts of the world, particularly in developing countries agriculture is the major livelihood of people, but primarily the most driver of land use change (Shiferaw, 2011). Relationship between various socio-economic conditions of the society, population pressure and physiographic feature, the land use type has resulted in land use change. Therefore, land use and land cover classification is used to analyse the interaction between socioeconomic and land use, which is contributed for the dynamics of land use and land cover change resulted from diversified and intensified agriculture and urbanization.

Understanding the changes in landscape patterns and their interactions with human activities and natural phenomenon are very essential for proper land management and decision improvement. Today, the data available from earth resource satellites are very applicable and useful for land use and land cover change detection studies (Song et al., 2011). With the aid of remote sensing and Geographical Information System (GIS) techniques, land use and land cover mapping has given a useful and detailed way to improve the selection of areas designed to agricultural, urban or industrial areas of a region (Deng et al., 2013; Dessie and Kleman, 2007). Application of remotely sensed data helps to determine the alterations in land cover in less time, at low cost and with better accuracy (NRSC and ISRO, 2011; FAO, 2004). Recent developments in GIS techniques provides suitable platform for data analysis, update and retrieval.

Although there have been extensive reports of current researches, there is still much unknown about the impacts of regional land use change on ecosystem management. Though various studies have under taken about the extent and status of clearing of forest, land cover change and soil erosion in many parts of Tamil Nadu, these studies feebly recognized the land cover dynamics and its driving force. Therefore, the prime objective of the study was to analyse and identify the land use and land cover dynamics and its driving force in upper Tamiraparani watershed in the past 17 years.

\section{Study area}

The watershed considered for the study is upper Tamiraparani which is located in the upper reach of Tamiraparani river basin, a region located in southern part of Tamil Nadu in India with a geographic location of $8033^{\prime}$ ' 01 " $\mathrm{N}$ and $8048^{\prime} 24$ " $\mathrm{N}$ latitude and 770 10' 16" E and 770 32' 02" E longitude. The upper Tamiraparani watershed covers an area of about 514.33 square kilometers holding a population density of 621 persons per square kilometer covering the major portions Tirunelveli district with agriculture as main economic activity of the people. The river Tamiraparani originates from Agasthiya malai on the eastern slopes of Western Ghats of India and confluences with Bay of Bengal near Palaya kayal as shown in Figure 1. The upper Tamiraparani watershed occupies the head reach of river Tamiraparani and comprises of two reservoirs namely Papanasam reservoir and Servalar reservoir the major portion of the watershed is covered by forest land which ranged densely vegetated trees (natural forest), plantations, shrubs and bushes. The watershed is characterized with diverse topographic conditions like mountainous, dissected terrain with moderate and steep slopes. The upper Tamiraparani watershed lies within the tropical monsoon zone. Based on the hydro-meteorological features the monsoon period is Southwest monsoon period spanning from June to September and Northeast monsoon period spanning from October to December with an annual average rainfall of the basin is about $1526 \mathrm{~mm}$. 
The major crops cultivated in the watershed are paddy, banana, sugarcane, pulses, fruits and vegetables. The educational levels of farmers are favorable to adopt modern water management practices and cropping pattern.

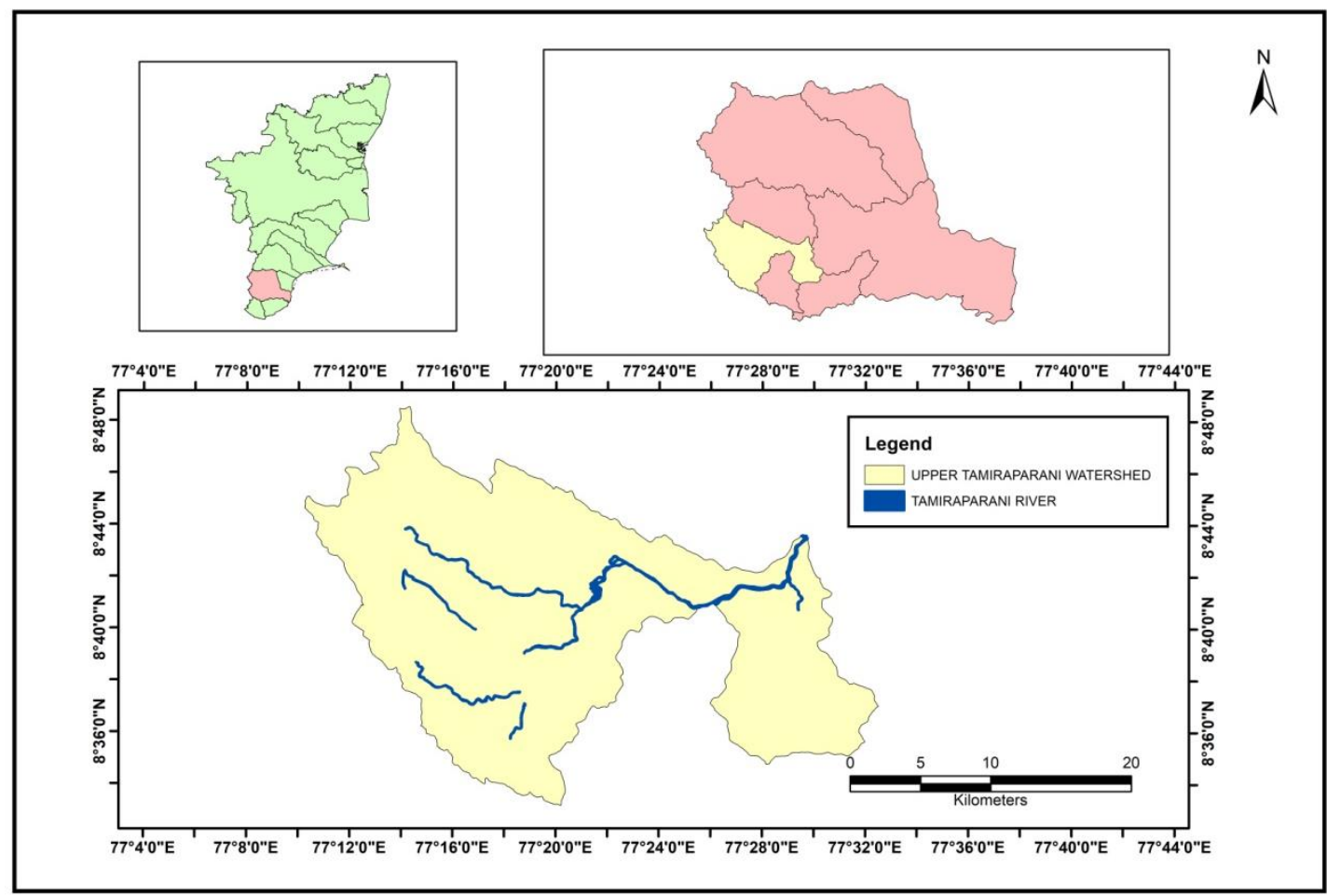

Figure 1. Index map of upper Tamiraparani watershed

\section{Data source and analysis method}

For the land cover and land use dynamics analysis the Landsat imagery was download from https://earthexplorer.usgs.gov/. The imagery was processes using ArcGIS 10.3 and classified with ERDAS IMAGE14 software. The details of the satellite data is presented in Table 1. Landsat 7 and Landsat 8 in path/row of 143/54 with spatial resolution of $30 \mathrm{~m}$ were taken for the study (Meshesha et al., 2016; Clevers et al., 2004). The land use and land cover change detection of the watershed under the study was analyzed for last 17 years. Supervised classification was carried out to classify the Landsat images (Carlson and Sanchez-Azofeifa, 1999; Baulies and Szejwach, 1998).

The parameters of the watershed like slope, slope length, slope width and stream network was obtained from the Digital Elevation Models (DEM) and the topography of the study area was defined by DEM which is used to describe the elevation of points for the given area at a spatial resolution of $30 \mathrm{~m} \times 30 \mathrm{~m}$. Finally about five land use and land cover were identified for the watershed. The five classes of use and land cover are given in Table 2. In order to get further information about the long term understanding of land use and land cover change practice in the watershed under study, focus group discussion have been conducted. For the discussion and in-depth interview elder peoples were selected as they assumed to have better local ecological information about the trend of land use and land cover change. 


$$
-4742
$$

Table 1. Materials and their source used for the analysis

\begin{tabular}{c|c|c|c|c|c|c}
\hline S. No & Images & Resolution (m) & Sensor & Path & Row & $\begin{array}{c}\text { Date } \\
\text { (dd-mm-yyyy) }\end{array}$ \\
\hline 1 & Landsat 7 & $30 \times 30$ & TM & 143 & 54 & $04-09-2001$ \\
2 & Landsat 7 & $30 \times 30$ & TM & 143 & 54 & $15-10-2013$ \\
3 & Landsat 8 & $30 \times 30$ & TM & 143 & 54 & $03-03-2018$ \\
\hline
\end{tabular}

Table 2. Description of land use and land cover class

\begin{tabular}{c|c|c}
\hline S. No. & Land use and land cover class & Description \\
\hline 1 & Forest land (FL) & $\begin{array}{c}\text { Region covered with thick natural forest, plantation forest } \\
\text { and riparian forest }\end{array}$ \\
\hline 2 & Agricultural land (AL) & $\begin{array}{c}\text { Land allotted for cultivation of crops in seasonal, annual and } \\
\text { perennial }\end{array}$ \\
\hline 4 & Urban built-up (UB) & $\begin{array}{c}\text { Settlements closely associated with cultivated land, urban } \\
\text { settlements, industrial and commercial buildings and } \\
\text { transportation regions }\end{array}$ \\
\hline 5 & Barren land (BL) & $\begin{array}{c}\text { Area with very little or no vegetation cover on land surface, } \\
\text { vulnerable soil to erosion and degradation. It also includes } \\
\text { bedrock which is unable to support cultivation }\end{array}$ \\
\hline
\end{tabular}

After the classification process the geographical extent of the land use and land cover in terms of hectare was calculated for each mentioned time periods and the extent of the change in land use type between the periods and within the periods was compared. The land use and land cover class has been performed using both ArcGIS10.3 and ERDAS IMAGINE14 and using the following formula necessary calculation has been engaged to know the rate of change in land use and land cover in hectare/year and percentage share of each class has studied in the time periods.

$$
\Delta \mathrm{A}(\%)=\frac{\text { At2-At1 }}{\text { At1 }} \times 100
$$

where $\Delta \mathrm{A}(\%)=$ change in area of land use and land cover class between the time interval At 1 and At 2 in percentage. At $1=$ area of land use and land cover type at initial time. At $2=$ area of land use and land cover type at final time.

The rate of change of land use and land cover type was calculated by the following formula:

$$
\Delta \mathrm{R}\left(\frac{\text { ha }}{\text { year }}\right)=\frac{\mathrm{z}-\mathrm{x}}{\mathrm{W}}
$$

where $\Delta \mathrm{R}=$ rate of change in hectare per year, $\mathrm{Z}=$ recent area of land use and land cover type in hectare, $X=$ previous area of land use and land cover type in hectare, $\mathrm{W}=$ the time interval that lapsed between $\mathrm{Z}$ and $\mathrm{X}$ in years. 


\section{Results and discussion}

\section{Land use and land cover map}

Combinations of red, green and blue bands were adopted to display the layer stacked image in the standard color composite. In order to carry out the analysis false color composite bands 2,3 and 4 used.

In order to meet the basic requirements of the increasing human population, agricultural land and urban and has increased in all parts of the world at the expense of other land use class such as forest, barren land and water bodies particularly in the developing countries where the greater part of inhabitants are depending on urban for their survival (Asres et al., 2016; Ayele et al., 2016). In the present study similar trend in the watershed has been found where agricultural land and settlement area have increased over time in all the time period of analysis. A considerable land use change has been observed in the study region since 1990s. To illustrate this substantial change through over time due to various uses and the overall change was presented in the year 2001, 2013 and 2018.

\section{Land use and land cover dynamics}

In the present study five classes of land use and land cover were presented namely forest land, agriculture land, urban land, barren land and water body. The land use and land cover dynamics is discussed in the following sections.

\section{Forest land}

The most prevailing land use cover class of the study catchment was forest resources which ranged densely vegetated trees (natural forest), plantations, shrubs and bushes. Thus in the study area, forest land occupies the major share of land cover class and the area covered by such forest could be deciduous, semi deciduous forest and mixed forest land. From the total area of the watershed in 2001 the share of the forest cover was $75 \%$, in contrast the coverage slightly decreased to $69.7 \%$ in the year 2013. It is evident that the decrease in forest cover corresponds to increase in the population and expansion of agricultural land. However, in 2018 the forest cover has regenerated by $1.4 \%$. The decrease of forest in the initial periods between 2001 and 2013 was around 2717.1 ha $(5.3 \%$ lost $)$, this is a considerable reduction in the forest cover given the expansion of built up area and agricultural fields and it is contradicted from the expectations. However, in the next period between 2013 and 2018 the share of the forest cover has increased by $1.4 \%$. Therefore, over the period of 17 years in between 2001 and 2018 the share has decreased by 3.9\%. On the basis of local ecological knowledge from interview and group discussion, factors like private and community level tree plantation helped in increasing the share of forest cover in later periods by $1.4 \%$ (between 2013 and 2018).

\section{Agricultural land}

Agricultural land is the region for crop cultivation for both annual and perennial crops. In the region under the study agriculture occupies a considerable land cover class (4.1, 7.7 and 5.3\% in 2001, 2013 and 2018 respectively). This implies that the agricultural land cover has been increased at the expense of forest land. This is due to rise in demand on account of population growth, additional farm land required to meet 
the food demand. Due to ever increase in cultivated land, farmer's exerted pressure on forest land and other barren land. This further hastened the erosion and degradation of soil and similar studies elsewhere states that alarming population rates resulted for the change of land cover class through time.

\section{Urban built-up}

The urban settlements in the study watershed have shown a persistent increase in the time period of analysis. The total area of the watershed covered by settlement has increased by 3.7\% from 2001 to 2013, 2.8\% from 2013 to 2018 (Figs. 2, 3, 4; Table 3). Unlike other types of land use systems, the growth rate of both rural and urban settlements took the largest share by covering other land use types for instance forest, bushes, water bodies, agriculture and barren land. In the time period of study (20012018) there has been $6.5 \%$ increase of settlement land within the last 17 years. This is because of continuous increase in population number they need addition land for settlement area, which costs 3319.11 ha of other land use type.

Table 3. Land use and land cover area of upper Tamiraparani watershed

\begin{tabular}{c|c|c|c|c|c|c}
\hline \multirow{2}{*}{ LULC classes } & \multicolumn{5}{|c}{ Land use and land cover area (ha) and percentage share } \\
\cline { 2 - 7 } & \multicolumn{2}{|c|}{2001} & \multicolumn{2}{c}{$\mathbf{2 0 1 3}$} & \multicolumn{2}{c}{$\mathbf{2 0 1 8}$} \\
\cline { 2 - 7 } & Area (ha) & \% & Area (ha) & \% & Area (ha) & \% \\
\hline Forest land & 38615.7 & 75.0 & 35898.6 & 69.7 & 36606.2 & 71.1 \\
Agricultural land & 2097.1 & 4.1 & 3972.9 & 7.7 & 2727.6 & 5.3 \\
Urban built-up & 1414.9 & 2.7 & 3311.3 & 6.4 & 4734.0 & 9.2 \\
Barren land & 8501.0 & 16.5 & 7518.8 & 14.6 & 6859.4 & 13.3 \\
Water body & 872.7 & 1.7 & 799.8 & 1.6 & 574.1 & 1.1 \\
Total & 51501.3 & 100 & 51501.3 & 100 & 51501.3 & 100 \\
\hline
\end{tabular}

\section{Barren land}

This type of land use within the stated years has shown continuously decreasing trend from $16.5 \%$ in 2001 to $14.6 \%, 13.3 \%$ in 2013 and 2018 respectively. With a declining trends in the first periods from 2001 to 2013 by $1.9 \%$ and further in the second periods from 2013 to 2018 further declined by $1.3 \%$. That is for the last 17 years; about $3.2 \%$ of barren land was changed into other type of land cover classes. This is due to ease of use of fixed plot of farm land in collaboration with alarming population rate growth negatively contributed for the decline of barren land.

\section{Water bodies}

This land use type includes reservoirs, ponds, lakes, streams and rivers within the watershed. In the study area water bodies covered only $1.7 \%$ in 2001 decreased to $1.6 \%$ in 2013 and further reduced to $1.1 \%$ in 2018 (Figs. 5, 6; Table 4). It is understood that this fluctuation water bodies in the analysis period (2001-2018) is that water harvesting habit of local people was low, though there is an increase in the rainfall trend within the watershed. 


$$
-4745-
$$

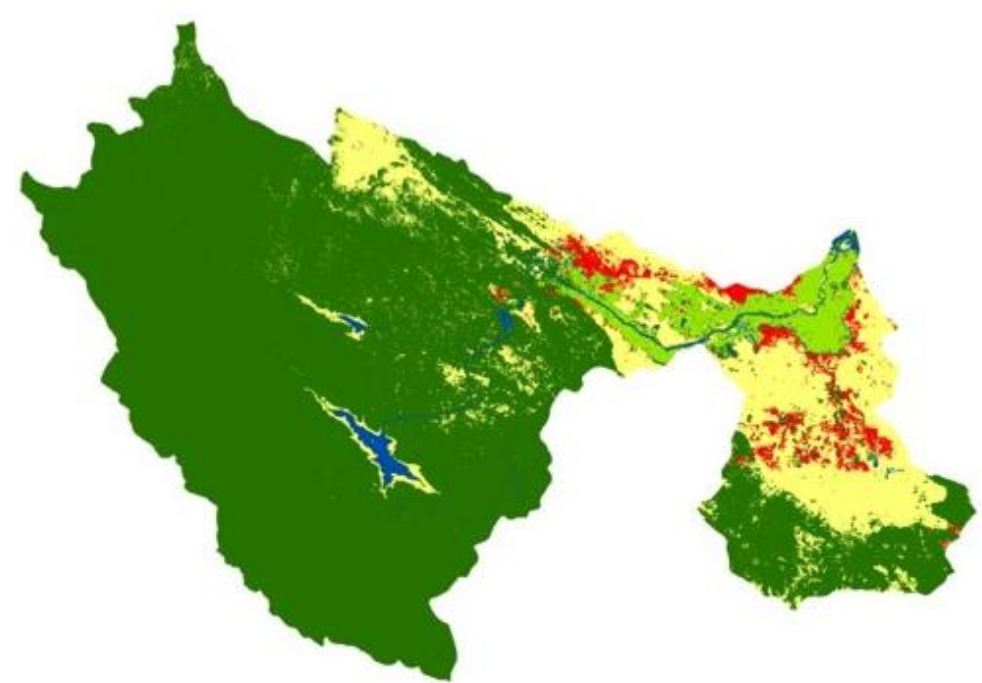

$N$

(a) LULC of Upper Tamiraparani Watershed 2001

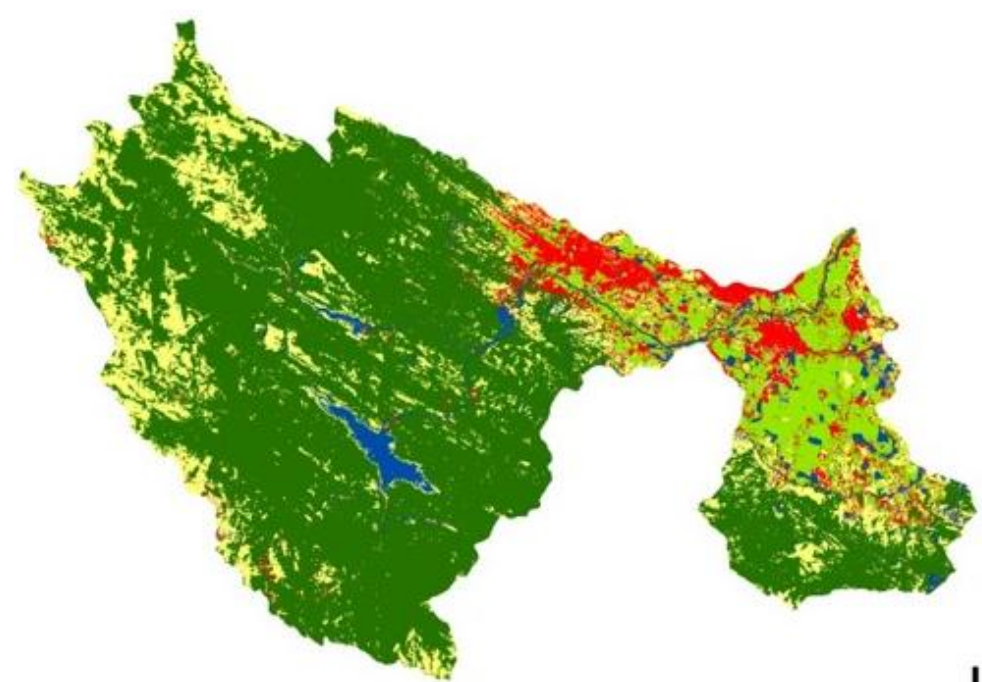

(b) LULC of Upper Tamiraparani Watershed 2013

\section{Legend}

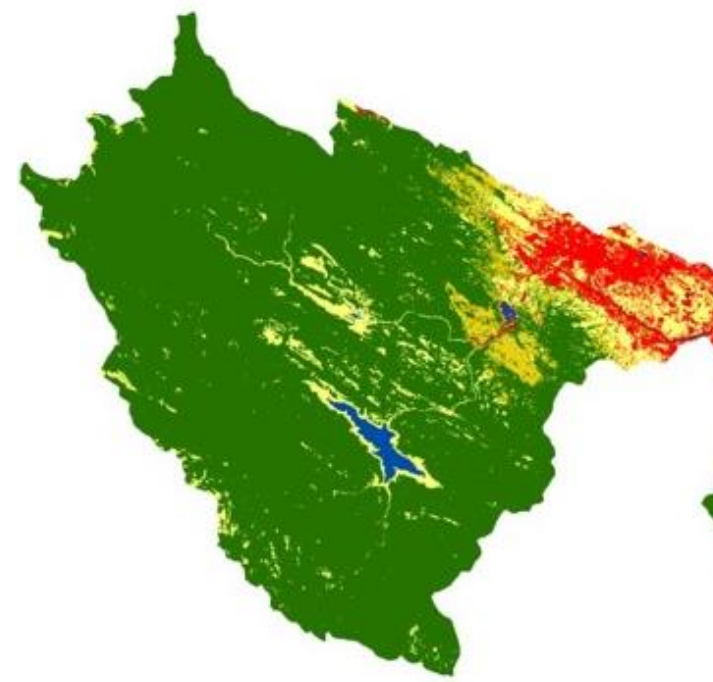

(c) LULC of Upper Tamiraparani Watershed 2018

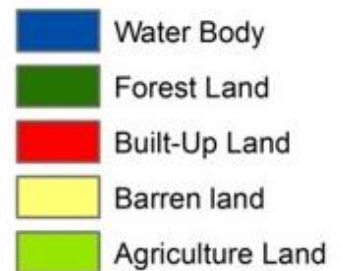

Figure 2. Land use and land cover map of upper Tamiraparani watershed 


$$
-4746-
$$

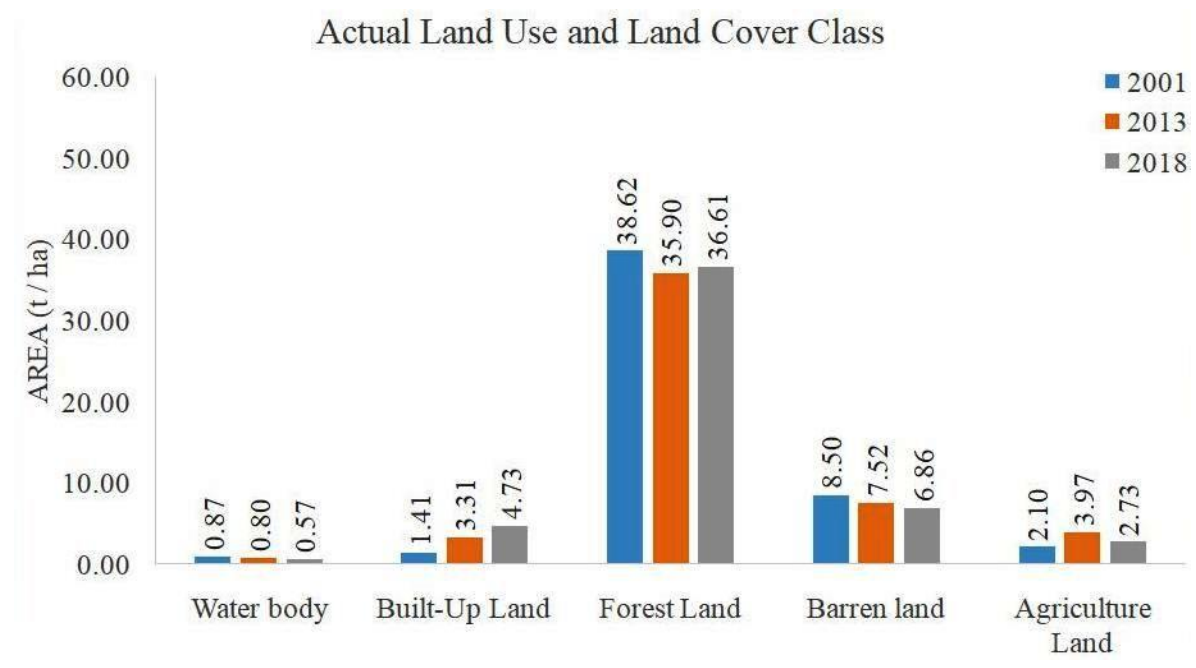

Figure 3. Land use and land cover type and area of upper Tamiraparani watershed in hectare

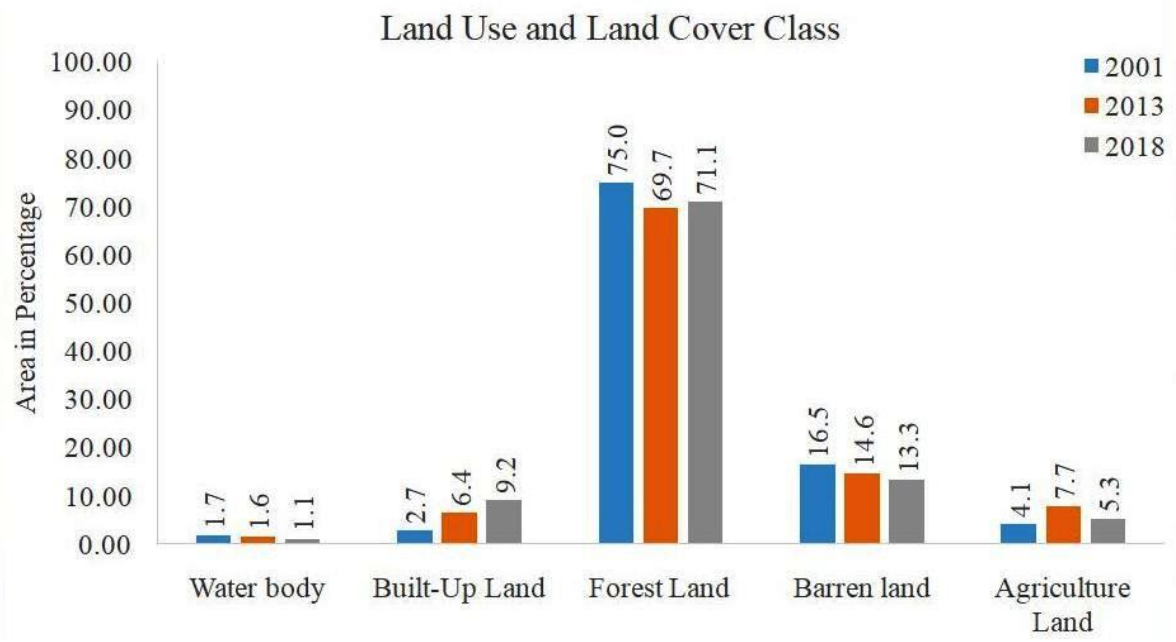

Figure 4. Percentage share of land use and land cover of upper Tamiraparani watershed

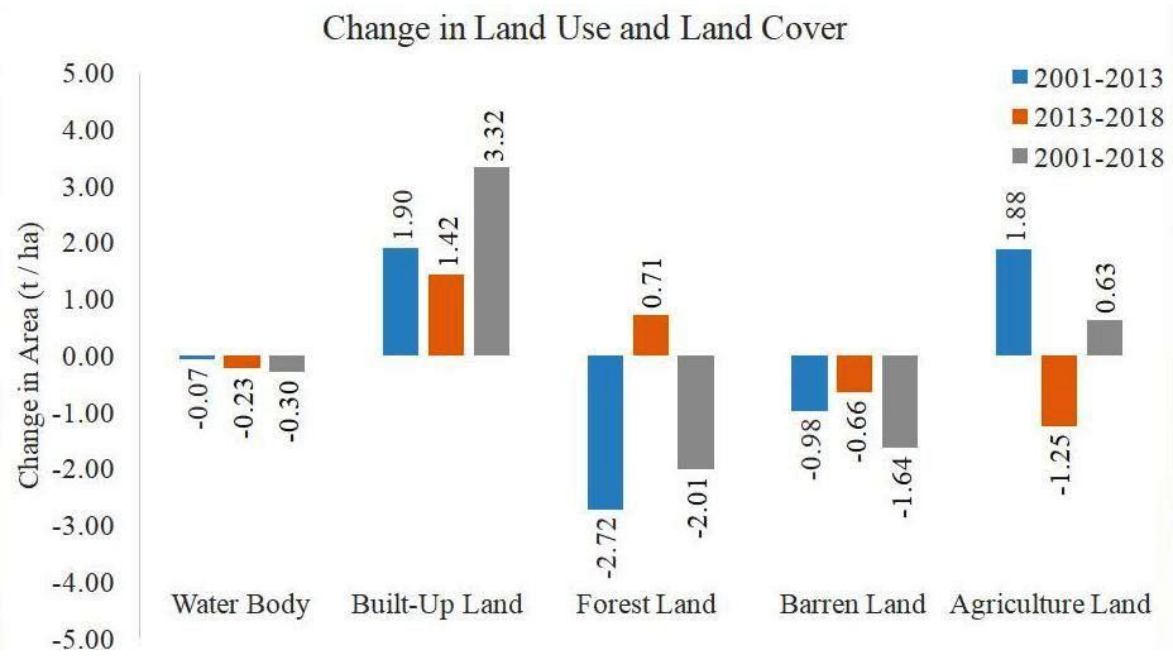

Figure 5. Change in land use and land cover of upper Tamiraparani watershed in hectare 


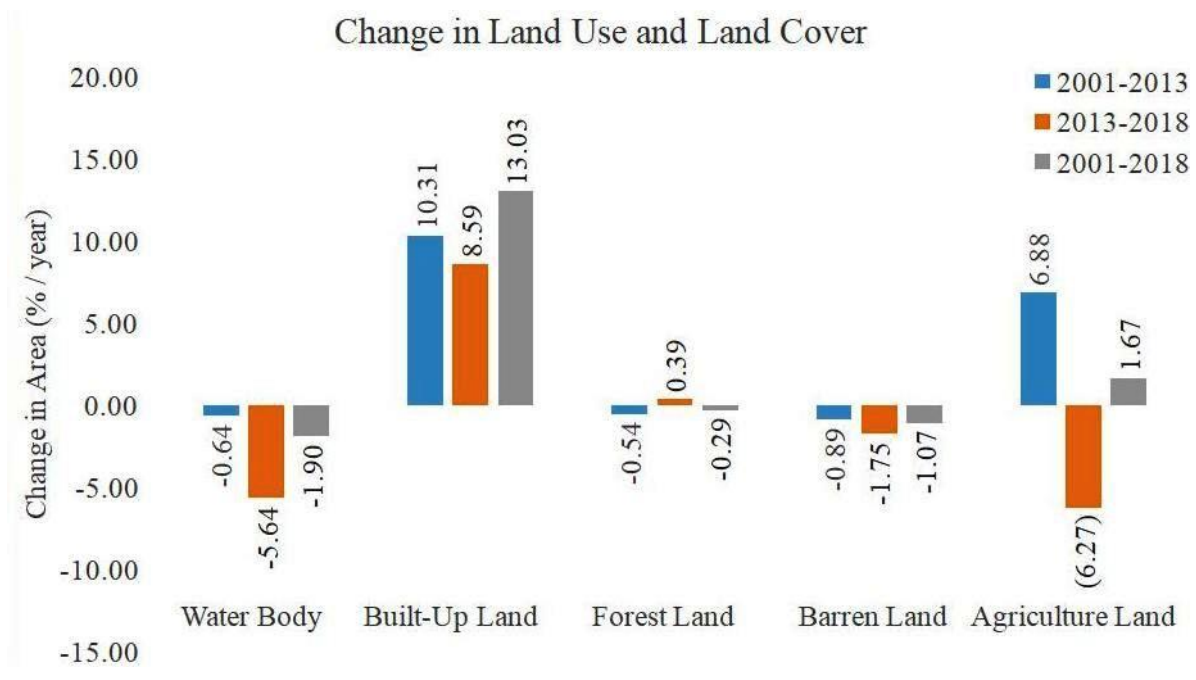

Figure 6. Percentage change of land use and land cover of upper Tamiraparani watershed

Table 4. Change in Land use and land cover of upper Tamiraparani watershed

\begin{tabular}{c|c|c|c|c|c|c}
\hline \multirow{2}{*}{ LULC classes } & \multicolumn{6}{|c}{ Change in land use and land cover (ha) and percentage share } \\
\cline { 2 - 7 } & \multicolumn{2}{|c|}{$\mathbf{2 0 0 1 - 2 0 1 3}$} & \multicolumn{2}{|c|}{$\mathbf{2 0 1 3 - 2 0 1 8}$} & \multicolumn{2}{|c}{$\mathbf{2 0 0 1 - 2 0 1 8}$} \\
\cline { 2 - 7 } & Area (ha) & \% & Area (ha) & \% & Area (ha) & \% \\
\hline Forest land & -2717.1 & -5.3 & +707.7 & +1.4 & -2009.4 & -3.9 \\
Agricultural land & +1875.8 & +3.6 & -1245.2 & -2.4 & +630.5 & +1.2 \\
Urban built-up & +1896.4 & +3.7 & +1422.7 & +2.8 & +3319.1 & +6.4 \\
Barren land & -982.2 & -1.9 & -659.4 & -1.3 & -1641.6 & -3.2 \\
Water body & -72.9 & -0.1 & -225.7 & -0.4 & -298.6 & -0.6 \\
\hline
\end{tabular}

\section{Rate of land use and land cover change dynamics}

The rate of change of forest land, agricultural land, built-up land, barren land and water bodies of Upper Tamiraparani watershed is presented in Table 5. This results states that though the resource is fixed, there exist various rate of change in different land cover types. However, the change rate of different land cover types has slightly variable among themselves.

The analysis indicates that between 2001 and 2013, agriculture land and built-up area has increased with the rate of $156.3 \mathrm{ha} /$ year and $158 \mathrm{ha} /$ year respectively caused for the outflow of other remaining land use classes. In the same period forest land, barren land and water body areas have decreased at the rate of 226.4 ha/year, 81.8 ha/year and 6.1 ha/year respectively. But, between the periods 2013 and 2018 expansion of urban built-up persistently increased with a rate of $284.5 \mathrm{ha} /$ year and in this period, in the forest land there exist an increment in rate of forest cover as $141.5 \mathrm{ha} / \mathrm{year}$. Unlike the previous period, unexpectedly with the increasing rate of urban built-up, the forest land has increased with a rate of 141.5 ha/year which is understood from the local investigation that the conservation of forest land has gained the importance within the watershed. However, agricultural land, barren land and water bodies rapidly decreased at the rate of 249 ha/year, 131.9 ha/year and 45.1 ha/year in between 2013 and 2018. Over the last 17 years expansion of agriculture land and urban built-up area increased 
with a rate of 37.1 ha/year and 195.2 ha/year respectively and contrary to this the share of forest land, barren land and water bodies shrunk with the respective rate of $118.2 \mathrm{ha} /$ year, $96.6 \mathrm{ha} /$ year and $17.6 \mathrm{ha} /$ year. The result of the finding is particularly urban built-up have intensively expanded at the expense of other land use and land cover without significant conservation measure.

Table 5. Rate of change in LULC of upper Tamiraparani watershed

\begin{tabular}{c|c|c|c}
\hline \multirow{2}{*}{ LULC classes } & \multicolumn{3}{|c}{ Rate of change (ha/year) } \\
\cline { 2 - 4 } & $\mathbf{2 0 0 1 - 2 0 1 3}$ & $\mathbf{2 0 1 3 - 2 0 1 8}$ & $\mathbf{2 0 0 1 - 2 0 1 8}$ \\
\hline Forest land & -226.4 & 141.5 & -118.2 \\
Agricultural land & 156.3 & -249.0 & 37.1 \\
Urban built-up & 158.0 & 284.5 & 195.2 \\
Barren land & -81.8 & -131.9 & -96.6 \\
Water body & -6.1 & -45.1 & -17.6 \\
\hline
\end{tabular}

\section{Conclusion}

In the last 17 years land use and land cover dynamics have undergone a considerable change in the upper Tamiraparani watershed. The observations in the land use and land cover dynamics showed the expansion of urban built-up and agricultural land as leading. On the other hand the forest land, water body and barren land declined. Though there exist overall decline in forest land, in recent five year (2013 to 2018) observation the trend of forest cover was increasing and this was possible because of the initiative of the local communities and government in conservation of the forest land. Similarly necessary action ought to be considered such that the water bodies within the watershed are also conserved with necessary rain water harvesting technologies. The increase in forest cover promotes the surrounding environmental condition because massive soil erosion and land degradation would be reduced. This could be possible only by proper integrated approach in conservation activities within the watershed considering both the upstream and downstream of the water bodies along with the forest cover. There should be appropriate land management activities in the barren lands such that the land cover in this region is conserved. Proper control should be maintained in the urban sprawl within the watershed, since this is in the upper reach of river Tamiraparani. In addition to this conservation of the riparian zones near the water bodies is highly essential to promote and maintain the health of the ecosystem within the watershed. In general, site-specific community-based awareness should be created among the community within the watershed for appropriate utilization of the available resources as well as the conservation of the scarce resources such that rehabilitation of environment is proved to be very effective.

\section{REFERENCES}

[1] Abate, S (2011): Evaluating the land use and land cover dynamics in Borena Woreda of South Wollo Highlands, Ethiopia. - J Sustainable Dev Afr 13(1): 1520-5509.

[2] Abbas, I. I., Muazu, K. M., Ukoje, J. A. (2010): Mapping land use-land cover and change detection in Kafur local government, Katsina, Nigeria (1995-2008) using remote sensing and GIS. - Res J Environ Earth Sci 2(1): 6-12. 
[3] Asres, R. S., Tilahun, S. A., Ayele, G. T., Melesse, A. M. (2016): Analyses of Land Use/Land Cover Change Dynamics in the Upland Watersheds of Upper Blue Nile Basin. - In: Melesse, A. M., Abtew, W. (eds.) Landscape Dynamics, Soils and Hydrological Processes in Varied Climates. Springer, Berlin, pp. 73-91.

[4] Ayele, G. T., Demessie, S. S., Mengistu, K. T., Tilahun, S. A., Melesse, A. M. (2016): Multitemporal Land Use/Land Cover Change Detection for the Batena Watershed, Rift Valley Lakes Basin, Ethiopia. - In: Melesse, A. M., Abtew, W. (eds.) Landscape Dynamics, Soils and Hydrological Processes in Varied Climates. Springer, Berlin, pp. 51-72.

[5] Bae, J., Ryu, Y. (2014): Land use and land cover changes explain spatial and temporal variations of the soil organic carbon stocks in a constructed urban park. - Landscape and Urban Planning 136: 57-67.

[6] Baulies, X., Szejwach, G (eds.) (1998): LUCC Data Requirements Workshop: Survey of Needs, Gaps and Priorities on Data for Land-Use/Land-Cover Change Research, Barcelona, 11-14 Nov 1997. - Institut Cartografic de Catalunya, Barcelona.

[7] Carlson, T. N., Sanchez-Azofeifa, G. A. (1999): Satellite remote sensing of land use changes in and around San Jose, Costa Rica. - Remote Sens Environ 70(3): 247-256.

[8] Clevers, J., Bartholomeus, H., Mucher, S., De Wit, A. (2004): Land cover classification with the medium resolution imaging spectrometer (MERIS). - EARSeL eProc 3(3): 354-362.

[9] Deng, X. Z., Liu, J. Y., Lin, Y. Z., Shi, C. C. (2013): A framework for the land use change dynamics model compatible with RCMs. - Advances in Meteorology. https://doi.org/10.1155/2013/658941.

[10] Dessie, G., Kleman, J. (2007): Pattern and magnitude of deforestation in the South Central Rift Valley Region of Ethiopia. - Mt Res Dev 27(2): 162-168.

[11] Dezso, Z., Bartholy, J., Pongracz, R., Barcza, Z. (2005): Analysis of land- use/land-cover change in the Carpathian region based on remote sensing techniques. - Phys Chem Earth, Parts A/B/C 30(1): 109-115.

[12] FAO (2004): Methodological Framework for Land Degradation Assessment in Dry Lands (LADA). - Food and Agriculture Organization (FAO), Rome.

[13] Meshesha, T. W., Tripathi, S. K., Khare, D. (2016): Analyses of land use and land cover change dynamics using GIS and remote sensing during 1984 and 2015 in the Beressa Watershed Northern Central Highland of Ethiopia. - Model. Earth Syst. Environ. 2: 1-12. https://doi.org/10.1007/s40808-016-0233-4.

[14] Minale, A. S., Rao, K. K. (2012): Impacts of land cover/use dynamics of Gilgel Abbay catchment of Lake Tana on climate variability, Northwestern Ethiopia. - Appl Geomat 4(3): $155-162$.

[15] NRSC, ISRO (2011): Manual on "Preparation of Geo Spatial Layers Using High Resolution (Cartosat-1 Pan + LISS-IV Mx) Orthorectified Satellite Imagery". - Space Based Information Support for Decentralized Planning (SIS-DP), Remote Sensing and GIS Applications Area National Remote Sensing Centre, Indian Space Research Organisation (ISRO), Department of Space, Government of India, Hyderabad.

[16] Nurelegn, M., Amare, S. (2014): Land use/cover dynamics in Ribb watershed, North Western, Ethiopia. - J Nat Sci 4(16): 9-16.

[17] Prakasam, C. (2010): Land use and land cover change detection through remote sensing approach: a case study of Kodaikanal taluk, Tamil Nadu. - Int J Geomat Geosci 1(2): 150.

[18] Praveen Kumar, M., Sreenivasula Reddy, J. R. (2013): Analysis of land use/land cover changes using remote sensing data and GIS at an urban area, Tirupati, India. - The Scientific World Journal. https://doi.org/10.1155/2013/268623.

[19] Shiferaw A. (2011): Evaluating the land use and land cover dynamics in Borena Woreda of South Wollo highlands, Ethiopia. - J Sustain Dev Afr 13(1): 87-107.

[20] Song, K. S., Wang, Z. M., Liu, Q. F., Liu, D. W., Ermoshin, V. V., Ganzei, S. S., Zhang, B., Ren, C. Y., Zeng, L. H., Du, J. (2011): Land use/land cover (LULC) classification with MODIS time series data and validation in the Amur River basin. - Geography and Natural Resources 32: 9-15. 